\title{
"Technology" Lessons At School Methodology Of Organization
}

\author{
Berdieva Khanifa Meleyvna, \\ PhD, Associate Professor, Head of the department the \\ regional center retraining and advanced training of public \\ educators of Surkhandarya region, \\ Termez, Uzbekistan
}

\author{
G open ACCESS \\ The American Journal of \\ Social Science And \\ Education Innovations \\ JULY 2020 \\ Page No.: 336-347 \\ Volume-II Issue-VII \\ PUBLISHED: 30 JULY 2020 \\ www.usajournalshub.com/inde \\ x.php/tajssei \\ Copyright: Original content \\ from this work may be used \\ under the terms of the \\ Creative Commons Attribution \\ 4.0 licence.
}

\section{Abstract}

The article deals with the application of knowledge, skills and abilities acquired in the teaching of the subject "Technology" in general secondary education in independent practical activities, the choice of profession, national and the formation of competencies to enter into social relations on the basis of universal values.

Keywords: school, teacher, student, class, education, upbringing, technology, competence, stage, direction, national, folk craft, profession, efficiency.

\section{Introduction}

The Action Strategy on the five priority areas of development of the Republic of Uzbekistan, adopted on the direct initiative and under the leadership of the President of the Republic of Uzbekistan Sh.M. Mirziyoyev, has launched a new stage of development in the republic. The practical results of this process are reflected in all spheres of our lives today, and most importantly, in the minds, aspirations and actions of our people.

Particular attention is paid to the improvement of the education system, which is one of the priorities of the fourth strategy of action - the development of the social sphere ${ }^{1}$. 
1 Decree of the President of the Republic of Uzbekistan "On the strategy of further development of the Republic of Uzbekistan". Tashkent, February 7, 2017. PF-49471.

In his speeches and conversations at various meetings, the head of our state stressed the need to raise the issues of upbringing a harmoniously developed generation and a healthy lifestyle for young people. As the President said: "If we do not bring up our children properly, if we are not aware of their behavior and mood every day, every minute, if we do not teach them science and profession, if we do not find a decent job, this deposit will be rich. It's okay to give up. ${ }^{2}$ "

It is known that the Laws "On Education" and "On the National Training Program" 3 also define the tasks of training highly qualified specialists in our country who can meet the requirements of world standards. In particular, the goal of the National Program of Personnel Training is to radically reform the education system, to rid it of the ideological views and stereotypes of the past, to develop a national system of training qualified personnel at the level of developed democracies, meeting high moral and ethical requirements. is to create.

The subject of "Technology" in general secondary schools has a special significance in the activities of students and school life, as it is taught for a long time, ie from the first grade to the last grade. . The subject of "Technology" in the school is organized in three stages, the purpose of which is to develop students' physical development, to acquaint them with the world and people of labor, tools and practices, the main industries and professions, the use of tools, the development of labor skills in the production of simple items, consciously focused on the choice of profession [12, p.24].

Each of the above steps has specific tasks. For example, in the 1st grade in the subject "Technology" in grades 1-4.

2 Mirziyoyev Sh. Let's work together for the fate and future of our country. // "People's speech", June 16, 2017.

3 Laws of the Republic of Uzbekistan "On Education" and "On the National Training Program". -T .: "Sharq", 1997 
students will be introduced to the role of labor in people's lives, the simplest labor practices and tools, and their use. From paper, glue, fabric, yarn, and plasticine to simple tools and toys, such as needles, scissors, and knives, basic skills are developed.

\section{The Main Findings And Results}

"Technology" lessons of the 2nd stage consist of "Technology" lessons of 5-7 grades. Technology courses at this stage are organized in technology and design (metal and wood processing technology), service (cooking basics and fabric processing technology), and general areas. These are the most important forms of production and are used in almost every field. For example, in grades 5-7, students are introduced to the basics of production: wood, metal, fabric processing and cooking, electrical engineering, and repair. , in these areas they develop work skills, which in the future will be directed to the conscious choice of a profession.

Level 3 Technology Classes are Technology Classes for Grades 8-9, which are organized in three areas as above. The main difference between this and the second phase is that the Technology courses in this phase provide more direct advice to students on career choices and the basics of production. It teaches students about the types of professions, their characteristics, what to look for when choosing a profession. It is up to the students to choose which of these professions to pursue.

The main task of teaching these "Technology" subjects is to ensure the proper physical development of students, the development of creative abilities and practical skills. This leads to the following goals and objectives.

\section{The purpose of "Technology" lessons:}

In technology classes, students are introduced to the production process, areas of 
production, equipment and machinery used in them, their types and uses, and are taught how to make simple items.

In the course of the subject "Technology" to further strengthen the professional orientation of students by teaching them to work on various natural and metallic and nonmetallic materials on the basis of technological methods, to learn the basics of folk crafts, household sciences, electrical engineering. acquisition of knowledge, skills and abilities for vocational training and the formation of the ability to apply them in life.

\section{The main purpose of teaching the subject "Technology" in general secondary} education is to apply the knowledge, skills and abilities acquired by students in the field of technical and technological operations in independent practical activities, to choose a profession. , the formation of competencies to enter into social relations on the basis of national and universal values.

\section{The main objectives of the subject "Technology" taught in secondary schools:}

- teaching materials and information about their properties, properties and technical object and technological processes;

- knowledge of technical objects and special and general labor operations in technological processes;

- be able to manage technological processes, apply special and general labor operations;

- formation of technical and creative thinking, intellectual abilities;

- be able to analyze the technological process and the sequence of execution of finished products, as well as product quality;

- to draw conclusions on the implementation of labor processes in the manufacture of goods and to assess labor operations, product quality;

- The formation and development of competencies in the field of "Technology" and the basis for the implementation of conscious preparation for career choice. 
In general secondary schools, the subject "Technology" is taught in general in the primary grades, in grades 5-9 in the areas of "Technology and Design", "Service" and "General" [7, P.124 ].

The subject "Technology" is taught in the following sections.

\section{In grades 1-4:}

1. Work with paper and cardboard.

2. Working with natural and various materials.

3. Working with fabrics and fibrous materials.

4. Artistic construction and technical modeling.

\section{In grades 5-7:}

\section{Technology and design}

1. Woodworking technology.

2. Technology of processing of polymeric materials.

3. Metalworking technology.

4. Electrical work.

5. Basics of household sciences.

\section{Service direction}

1. Basics of cooking.

2. Fabric processing technology.

3. Basics of household sciences.

\section{In grades 8-9:}

\section{Technology and design}

1. Technology of folk crafts.

2. Basics of production and household.

3. Basics of electronics.

4. Technology of creative project preparation.

5. Career guidance.

I. Service direction

1. Technology of folk crafts.

2. Basics of production and household.

3. Basics of electronics. 
4. Technology of creative project preparation.

5. Career guidance.

If there are enough qualified teachers, it is allowed to teach the subject of "Technology" in two groups in general secondary schools with a number of 25 or more students in grades V-IX.

Each lesson is organized in accordance with safety rules and sanitary-hygienic requirements.

Students will also be provided with information on the types of professions in the field of "Technology".

In the Republic of Uzbekistan, based on the priority of continuity of education, membership, personality and interests of students, basic competencies are formed in accordance with their age.

\section{Communicative competence}

\section{A1}

Be able to use technology terms in communication; simple description of the appearance of the product; ask and answer questions on a topic; to be polite in communication, to listen to the opinion of the interlocutor, to be able to express one's opinion;

\section{A1 +}

To behave in different situations at school, on the street, at home, to follow the culture of communication; independent thinking based on the acquired knowledge; react independently to manufactured items.

\section{Competence in working with information:}

\section{A1}

Watching and listening to TV and radio programs and broadcasts on the subject of "Technology", studying the methods of work, studying the information in magazines and newspapers;

\section{A1 +}

To be able to use information sources (television, radio, audio-video recording, telephone) in the performance of didactic tasks, using the media to find terms related to the subject "Technology"; adhere to media culture when opening files.

\section{Self-development competence}

\section{A1}


Study of the subject "Technology"; to be clean in practical work, to listen to adults, to study sciences in the "Skillful hands" circle, to have such qualities as diligence, honesty, respect; to be the right word, to explain the mistakes of peers, to help adults, children, peers, to increase their knowledge through learning;

\section{A1 +}

Regular reading and study of various books on "Technology"; to understand one's mistakes and shortcomings, to try to correct one's mistakes, to control oneself.

\section{Socially active civic competence}

\section{A1}

Know your student's duties and responsibilities, follow them, and have a place in the classroom and family; help adults, peers, and children, participate in school and extracurricular activities, and adhere to a culture of respect (respect for elders, respect for the younger); understand their place and responsibilities in the family; preservation of school building, classroom equipment, furniture;

\section{A1 +}

Know and follow the duties of childhood and school; to know what rights he has in relation to his age, to take care of classroom equipment, teaching aids; participate in school, family, residential activities (various events, Saturdays, etc.).

\section{National and intercultural competence}

\section{A1}

Dress neatly and adhere to it at all times, be kind to friends, relatives and others, follow the example of adults in dressing and behaving modestly, and respect your home, school, and neighborhood; to observe cleanliness, to know national holidays, to have an understanding of the rules of etiquette of the student, to know the historical monuments of the area where he lives;

\section{A1 +}

Know the types of art and be able to distinguish them from each other, analyze works of art, follow the internal rules of the school; to distinguish between good and bad habits, to follow the etiquette of pilgrimage, to know national values (national-cultural traditions, holidays, celebrations).

\section{From mathematical literacy, science and technology news awareness and use competencies}

A1

Knowing how many people are in the family, who is older, who is younger, knowing when to go to school; be able to make daily plans; to be able to draw different diagrams in daily activities, to know the holidays in our country; understand the meaning of waste 
and thrift and apply it in daily life;

\section{A1 +}

Be able to use the necessary teaching aids, raw materials in the course of the lesson, to calculate the cost per day; know the types of techniques and when they appeared.

\section{Communicative competence:}

\section{A2}

Be able to express terms related to the subject "Technology" in foreign languages, to communicate with their friends in the language of technology; be able to ask and answer questions logically based on the topic; adherence to a culture of communication, ability to work in a team;

A2 +

Defending and persuading one's position by analyzing the opinion of the interlocutor in a conversation on the subject of "Technology"; to manage their passions in various conflict situations, to treat disagreements fairly, justly and positively, and to make the necessary decisions.

\section{Competence in working with information}

\section{A2}

Use available sources of information (Internet, television, radio (audio-video recording), telephone, computer, e-mail); to search, sort, process, transmit, secure and use the media culture in order to find the information necessary for the study of the subject "Technology" in the media;

\section{A2 +}

Be able to work with documents encountered in daily activities, search, study, analyze, apply sources related to technological maps and schemes.

\section{Self-development competence}

\section{A2}

In-depth study of the subject "Technology" in the field, to bring their inventions to the field in accordance with today's requirements, to be able to approach the design profession in the manufacture of each product, to constantly learn as a person 'selfdevelopment; take responsibility for working in groups, be a leader, make the right decisions in different problematic situations; to exercise their constitutional rights and duties properly; striving for physical, spiritual, mental and intellectual maturity;

\section{A2 +}

To be able to demonstrate their abilities as a person according to their interests, to make conscious career choices, to have human qualities such as honesty, integrity. 


\section{Socially active civic competence}

\section{A2}

Knowledge of the concepts of "sound faith" and "worldview"; not to be indifferent to the events in the society, to express one's attitude; understanding and conscious choice of professions;

\section{A2 +}

Knowledge and observance of human and civil rights, freedoms and duties. National and intercultural competence

\section{A2}

To study, preserve and respect the historical, spiritual and cultural heritage of the people in the field of folk handicrafts, to respect their traditions and ceremonies;

\section{A2 +}

To study, preserve and respect their historical, spiritual and cultural heritage in the field of folk crafts, respect for traditions and ceremonies; to know and respect universal values.

\section{From mathematical literacy, science and technology news awareness and use competencies}

\section{A2}

Be aware of and be able to use scientific and technical innovations that facilitate human labor, increase productivity and create favorable conditions;

\section{A2 +}

To be able to tell about the role of our country in the world community and the period of its historical formation, to know the growth rates in all areas of our country during the years of independence; be able to read and use a variety of formulas, models, and diagrams in daily activities

- The formation and development of general labor skills and abilities in students, the formation and development of general labor culture, the qualities that form the basis for the choice of professions according to their interests, abilities, professional inclinations;

- The mental and physical actions performed by students, aimed at the creation of material goods, are a process of labor, the acquisition of knowledge about the tools, 
means and processes of labor, as well as production labor and skills in a particular field, conscious choice of profession and aimed at developing personal qualities and thinking that allow them to engage in labor activities for the benefit of society and the individual. Therefore, the subject "Technology" is defined in the STS as follows:

- Training in the basics of the content of various industries, the use of measuring instruments, data sources, the implementation of labor practices, the ability to draw conclusions by comparing the results of work with the established requirements;

- To provide knowledge about the techniques and technologies used in various sectors of the economy, to enable them to get acquainted with various areas of human activity through practical work;

\section{Socially active civic competence}

A2

Knowledge of the concepts of "sound faith" and "worldview"; not to be indifferent to the events in the society, to express one's attitude; understanding and conscious choice of professions;

\section{A2 +}

Knowledge and observance of human and civil rights, freedoms and duties.

National and intercultural competence

\section{A2}

To study, preserve and respect the historical, spiritual and cultural heritage of the people in the field of folk handicrafts, to respect their traditions and ceremonies;

\section{A2 +}

To study, preserve and respect their historical, spiritual and cultural heritage in the field of folk crafts, respect for traditions and ceremonies; to know and respect universal values.

\section{From mathematical literacy, science and technology news awareness and use competencies}

\section{A2}

Be aware of and be able to use scientific and technical innovations that facilitate human labor, increase productivity and create favorable conditions;

\section{A2 +}

To be able to tell about the role of our country in the world community and the period of its historical formation, to know the growth rates in all areas of our country during the years of independence; be able to read and use a variety of formulas, models, and diagrams in daily activities

\section{Conclusions}

- The formation and development of general labor skills and abilities in students, the formation and development of general labor culture, the qualities that form the basis for the choice of professions according to their interests, abilities, professional inclinations; 
- The mental and physical actions performed by students, aimed at the creation of material goods, are a process of labor, the acquisition of knowledge about the tools, means and processes of labor, as well as production labor and skills in a particular field, conscious choice of profession and aimed at developing personal qualities and thinking that allow them to engage in labor activities for the benefit of society and the individual. Therefore, the subject "Technology" is defined in the STS as follows:

- training in the basics of the content of various industries, the use of measuring instruments, data sources, the implementation of labor practices, the ability to draw conclusions by comparing the results of work with the established requirements;

- to provide knowledge about the techniques and technologies used in various sectors of the economy, to enable them to get acquainted with various areas of human activity through practical work;

\section{References}

1. Mirziyoyev Sh.M. We will build our great future together with our brave and noble people. -T .: "O'zbekiston", 2017. - 488 p.

2. Mirziyoyev Sh. Let's work together for the fate and future of our country. // People's speech, June 16, 2017.

3. Decree of the President of the Republic of Uzbekistan "On the Strategy of Actions for the Development of the Republic of Uzbekistan" // People's Speech, February 8, 2017. № 28.

4. Laws of the Republic of Uzbekistan "On Education" and "On the National Training Program". -T .: "Sharq", 1997.

5. Babanskiy Yu.K. Modern general education teaching methods. -T :: "Teacher", 1990. - 232 p.

6. Karimov I. Coordinated technologies for the organization of creative activity of students in labor education: Monograph, methodological direction. $-\mathrm{T}$.: "Sparks of literature", 2015. - 172 p.

7. Muslimov N.A. and b. Methods of teaching labor education and career guidance: Textbook. -T., 2014.- 124 p. 
8. Sharipov Sh.S. and b. Technology: Textbook, 6 p.m. -T .: "Sharq", 2017.

9. Sharipov Sh.S. and b. Technology: Textbook, 7 p. -T .: "Sharq", 2017.

10. Sattorova Z. and b. Technology: Textbook for 9th grade. -T .: "O'zbekiston", 2019. -160 p.

11. Shomirzayev M.X. Ways to increase the effectiveness of teaching technology. $-T$ : 2019. - 72 p.

12. Shomirzayev M.X., Karimov I.I. Innovative pedagogical technologies in teaching technology.- T .: "University", 2020. - 192 p. 